by Giuliano F. Panza ${ }^{1,2}$, Antonella Pontevivo ${ }^{1}$, Giordano Chimera ${ }^{1}$, Reneta Raykova ${ }^{1}$, and Abdelkrim Aoudia ${ }^{1,2}$

\title{
The lithosphere-asthenosphere: Italy and surroundings
}

1 Department of Earth Sciences, University of Trieste, Via Weiss 4, 34127 - Trieste, Italy. panza@ dst.units.it

2 The Abdus Salam International Centre for Theoretical Physics, SAND Group, Trieste, Italy.

The velocity-depth distribution of the lithosphereasthenosphere in the Italian region and surroundings is imaged, with a lateral resolution of about $100 \mathrm{~km}$, by surface wave velocity tomography and non-linear inversion. Maps of the Moho depth, of the thickness of the lithosphere and of the shear-wave velocities, down to depths of $200 \mathrm{~km}$ and more, are constructed. A mantle wedge, identified in the uppermost mantle along the Apennines and the Calabrian Arc, underlies the principal recent volcanoes, and partial melting can be relevant in this part of the uppermost mantle. In Calabria, a lithospheric doubling is seen, in connection with the subduction of the Ionian lithosphere. The asthenosphere is shallow in the Southern Tyrrhenian Sea. High velocity bodies, cutting the asthenosphere, outline the Adria-Ionian subduction in the Tyrrhenian Sea and the deep-reaching lithospheric root in the Western Alps. Less deep lithospheric roots are seen in the Central Apennines. The lithosphere-asthenosphere properties delineate a differentiation between the northern and the southern sectors of the Adriatic Sea, likely attesting the fragmentation of Adria.

\section{Introduction}

The first definition of the gross features of the lithosphere-asthenosphere system in Italy and surroundings dates back to Panza et al. (1980) and it is chiefly based on the analysis of Rayleigh wave dispersion. More recent models are based both on surface waves (e.g. Marquering and Snieder, 1996; Martinez et al., 1997, 2000, 2001; Ritzwoller and Levshin, 1998; Yanovskaya et al., 1998, 2000; Pasyanos et al., 2001; Karagianni et al., 2002; Pontevivo and Panza, 2002) and body waves tomography (e.g. Gobarenko, 1990; Spakman, 1990; Babuska and Plomerova, 1990; Alessandrini et al., 1995, 1997; Papazachos et al., 1995; Papazachos and Kiratzi, 1996; Cimini and De Gori, 1997; Parolai et al., 1997; Piromallo and Morelli, 1997; Bijwaard et al., 1998; Lucente et al., 1999). Based on the existing information derived both from refraction and reflection experiments, and body-wave and surface-wave tomography, a compilation of the compressional velocity $\left(\mathrm{V}_{\mathrm{p}}\right)$, shear velocity $\left(\mathrm{V}_{\mathrm{s}}\right)$, and density $(\rho)$ distribution in space is due to Du et al. (1998).

We show here features of the lithosphere-asthenosphere system that characterize Italy and surroundings, with a multiscale lateral resolution, as obtained from the simultaneous inversion of regionalized surface wave tomography (e.g. Pontevivo and Panza, 2002; Panza and Pontevivo, 2002; Chimera et al. 2003) and refraction and reflection seismology data (e.g. Aljinovic and Blaskovic, 1987; Bally et al., 1986; Blundell et al., 1992; Catalano et al., 1996, 2001; Cerno-
Doglioni et al., 2001; Ferrucci et al., 1991; Finetti et al., 2001; Gentile et al., 2000; Improta et al., 2000; Kissling and Spakman, 1996; Morelli, 1998; Mostaanpour, 1984; Pepe et al., 2000; Pialli et al., 1995, 1998; Scarascia and Cassinis, 1997).

\section{Data and method}

The data and methods used to obtain the tomographic maps are described by Pontevivo and Panza (2002), Panza et al. (2003a), Chimera et al. (2003), Levshin et al. (1972, 1992), Ditmar and Yanovskaya (1987) and Yanovskaya and Ditmar (1990). The tomographic maps can be discretized with a proper grid and for each cell of the grid the cellular average group or phase velocity curve is computed. The cellular dispersion curves can be grouped according to their shape and average value (e.g. Panza et al., 2003b) to define regional properties. The lateral resolving power common to most of the available surface-wave tomography (Pontevivo and Panza, 2002) is of about 200 $\mathrm{km}$, but if some parameters of the uppermost part of the crust are fixed on the base of a priori independent geological and geophysical information, the lateral resolving power of the cellular mean dispersion curves can be improved and this justifies the choice to perform the inversion for cells of $1^{\circ} \times 1^{\circ}$ (Panza and Pontevivo, 2002; Panza et al., 2003a). If dispersion relations are available for periods as low as $1 \mathrm{sec}$, local studies can be performed at the scale of a few tens of $\mathrm{km}$.

Due to the complexity of the area we prefer non-linear inversion, since it is independent from the initial model. Through the non-linear inversion, known as the hedgehog method (Valyus et al., 1969; Valyus, 1972; Knopoff, 1972), of the group and phase velocity curves at regional, cellular and local scale, average multiscale lithospheric models that reach a depth of about $250 \mathrm{~km}$ are obtained. As a priori information, we use the existing literature. In the inversion, the unknown Earth model is replaced by a set of parameters and the definition of the structure is reduced to the determination of the numerical values of these parameters. In the elastic approximation, the structure is modelled as a stack of $\mathrm{N}$ homogeneous isotropic layers, each one defined by four parameters: $V_{\mathrm{p}}, \mathrm{V}_{\mathrm{s}}, \rho$ and thickness. Each parameter can be fixed (during the inversion the parameter is held constant accordingly to independent geophysical evidences - the a priori information), independent (the variable parameters that can be well resolved by the data) or dependent (the parameter has a fixed relationship with an independent parameter). For each cell, a set of solutions, which are consistent with the observations and with the resolving power of the data (Knopoff and Panza, 1977; Panza 1981), is obtained.

\section{Retrieval of multiscale structural models}

In Figure 1, three examples of models of the crust and of the upper mantle are presented. In each frame, the inverted dispersion data, the set of solutions (thin lines) $\mathrm{V}_{\mathrm{s}}$ versus depth, the explored part of the parameters space (grey area), and the chosen solution (bold line) are shown. It could be attractive to consider as solution a median of 


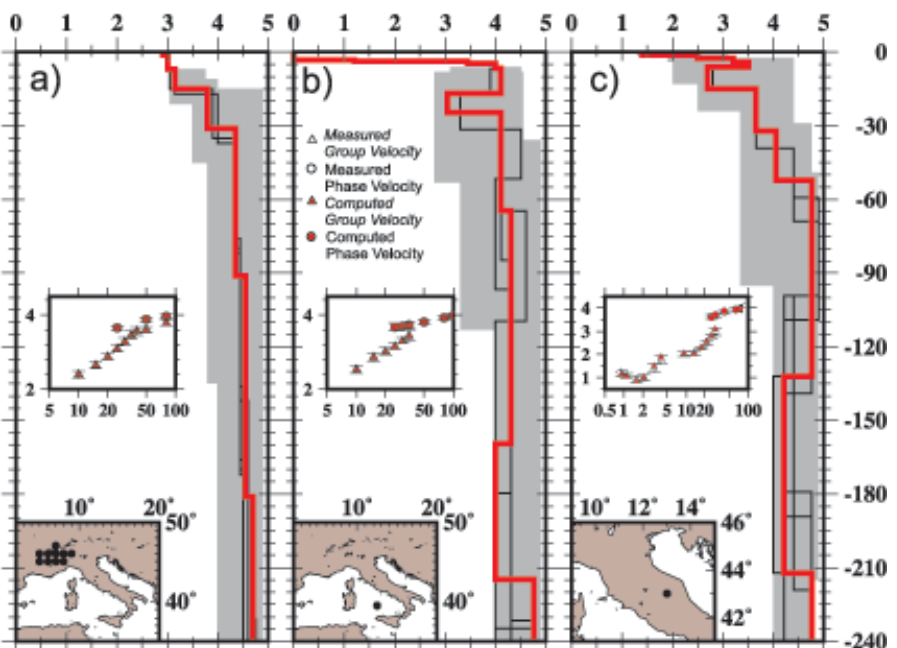

Figure 1 Models $\left(V_{s}\right)$ of crust and upper mantle for: (a) Western Alps, (b) $1^{\circ} \times 1^{\circ}$ cell containing Vavilov Seamount, (c) part of UMD; as marked by dots. In each frame, measured (with error bars) and computed dispersion relations are given; thin lines: set of solutions; grey area: explored part of the parameters space; bold line: chosen solution.

of the representative solution there is a tenet of modern science known as Occam's razor: it is vain to do with more what can be done with fewer (Russel, 1946). To reduce the effects of the projection of possible systematic errors into the inverted model, the root mean square (r.m.s.) of the chosen solution is as close as possible to the average r.m.s. computed from all the solutions.

The set of solutions in Figure 1a corresponds to the Western Alps region defined by Panza et al. (2003b). Due to the complexity of the Alpine domain, at crustal level, the model is formally correct but has no straightforward geological significance. On the other side at mantle level, the slight increase of $\mathrm{V}_{\mathrm{s}}$ from about $4.35 \mathrm{~km} / \mathrm{sec}$, just below the Moho, to about $4.7 \mathrm{~km} / \mathrm{sec}$, at depths larger than $180 \mathrm{~km}$, is consistent with the presence of lithospheric roots, as first indicated by Panza and Mueller (1979).

In Figure $1 \mathrm{~b}$, the solutions correspond to the $1^{\circ} \times 1^{\circ}$ cell in the central area of the Southern Tyrrhenian Sea, which contains the Vavilov Seamount (Panza and Pontevivo, 2002). The Moho is very shallow (about $7 \mathrm{~km}$ deep) and the lid thickness is less than $10 \mathrm{~km}$, with $\mathrm{V}_{\mathrm{s}}$ about $4.1 \mathrm{~km} / \mathrm{sec}$. Below this lid, there is a very well developed low velocity layer, centred at a depth of about $20 \mathrm{~km}$, with $\mathrm{V}_{\mathrm{s}}$ about 3.0 $\mathrm{km} / \mathrm{sec}$ and thickness of about $8 \mathrm{~km}$. This value of $V_{s}$ is consistent, accordingly with Bottinga and Steinmetz (1979), with about $10 \%$ of partial melting. The $\mathrm{V}_{\mathrm{s}}$ just below this very low velocity layer, about $4.1 \mathrm{~km} / \mathrm{sec}$, defines the uppermost asthenosphere. In the asthenosphere, $\mathrm{V}_{\mathrm{s}}$ varies between $4.1 \mathrm{~km} / \mathrm{sec}$ and $4.3 \mathrm{~km} / \mathrm{sec}$.

In Figure 1c, the chosen structure corresponding to the Umbria-Marche geological Domain (UMD) is characterized by a layered crust, about $32 \mathrm{~km}$ thick, with a relatively high velocity upper and lower crust ( $\mathrm{V}_{\mathrm{s}}$ about $\left.3.20-3.65 \mathrm{~km} / \mathrm{sec}\right)$ separated by a low-velocity transition zone $\left(\mathrm{V}_{\mathrm{s}}\right.$ about 2.75 $\mathrm{km} / \mathrm{sec}$ ) about $10 \mathrm{~km}$ thick. The Moho is followed by a relatively low velocity layer $\left(\mathrm{V}_{\mathrm{s}}\right.$ of about $\left.4.0 \mathrm{~km} / \mathrm{sec}\right)$, about 20 $\mathrm{km}$ thick. Below this layer, a lithospheric root, with $\mathrm{V}_{\mathrm{s}}$ about $4.75 \mathrm{~km} / \mathrm{sec}$, reaches the depth of about $130 \mathrm{~km}$, which is the top of the asthenosphere, with $\mathrm{V}_{\mathrm{s}}$ about $4.2 \mathrm{~km} / \mathrm{sec}$ and about $70 \mathrm{~km}$ thick. The outlined $\mathrm{V}_{\mathrm{s}}$ sequence versus depth in the uppermost mantle is consistent with the concept of mantle wedge, decoupling the crust from the underlying lithosphere. Therefore, we define mantle wedge the low velocity zone $\left(\mathrm{V}_{\mathrm{s}}\right.$ less than about $\left.4.2 \mathrm{~km} / \mathrm{sec}\right)$ in the uppermost mantle that overlies the high velocity lid $\left(\mathrm{V}_{\mathrm{s}}\right.$ greater than about $4.5 \mathrm{~km} / \mathrm{sec})$.

\section{Selected cross sections}

Examples of sections, crossing key areas, are given in Figure 2 (Panza and Pontevivo, 2002; Panza et al., 2003a; Chimera et al., 2003). In Figure 2b, two vertical sections trending NE-SW from the Tyrrhenian Sea across the Southern Apennines to the Dinarides are plotted. In the same sections, the shallow and intermediate-depth seismicity, with the depth error bars as given by ISC and falling in a stripe about $100 \mathrm{~km}$ wide and centred on the profiles, is shown.

The northernmost section AA' crosses Vavilov seamount in the Tyrrhenian Sea, Apennines, middle Adriatic Sea and Dinarides. Starting from A', the most evident feature is the presence of a high velocity lid, with $\mathrm{V}_{\mathrm{s}}$ about $4.8 \mathrm{~km} / \mathrm{sec}$. This lid reaches the maximum depth of about $155 \mathrm{~km}$ in the zone that goes from the western side of the Apennines to the Tyrrhenian coast. More to the southwest, this thick high velocity lid is missing. The section BB', less than about $100 \mathrm{~km}$ southeast of AA', crosses the Tyrrhenian Sea, the Vesuvio and Phlegraean Fields zone, the Gargano region, the Adriatic Sea and the Dinarides. Along BB', the high velocity body with $4.6 \leq V_{s} \leq 4.8 \mathrm{~km} / \mathrm{sec}$ reaches depths of about $110 \mathrm{~km}$ under the Dinarides, about $170 \mathrm{~km}$ under the Adriatic Sea and about $150 \mathrm{~km}$ under the western side of the Apennines. More to the southwest, below Vesuvio and Phlegraean Fields, the high velocity body extends to depths not less than $250 \mathrm{~km}$.

In Figure 2c, a balanced cross section from the Tyrrhenian to the Ionian Seas, along CC', is plotted down to $500 \mathrm{~km}$. Our data do not resolve deeper than about $250 \mathrm{~km}$, therefore, below this depth, the subducting Ionian lithosphere is outlined on the basis of the (a)

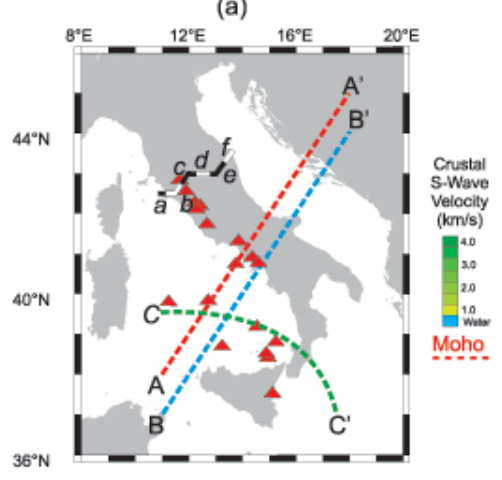

(c)
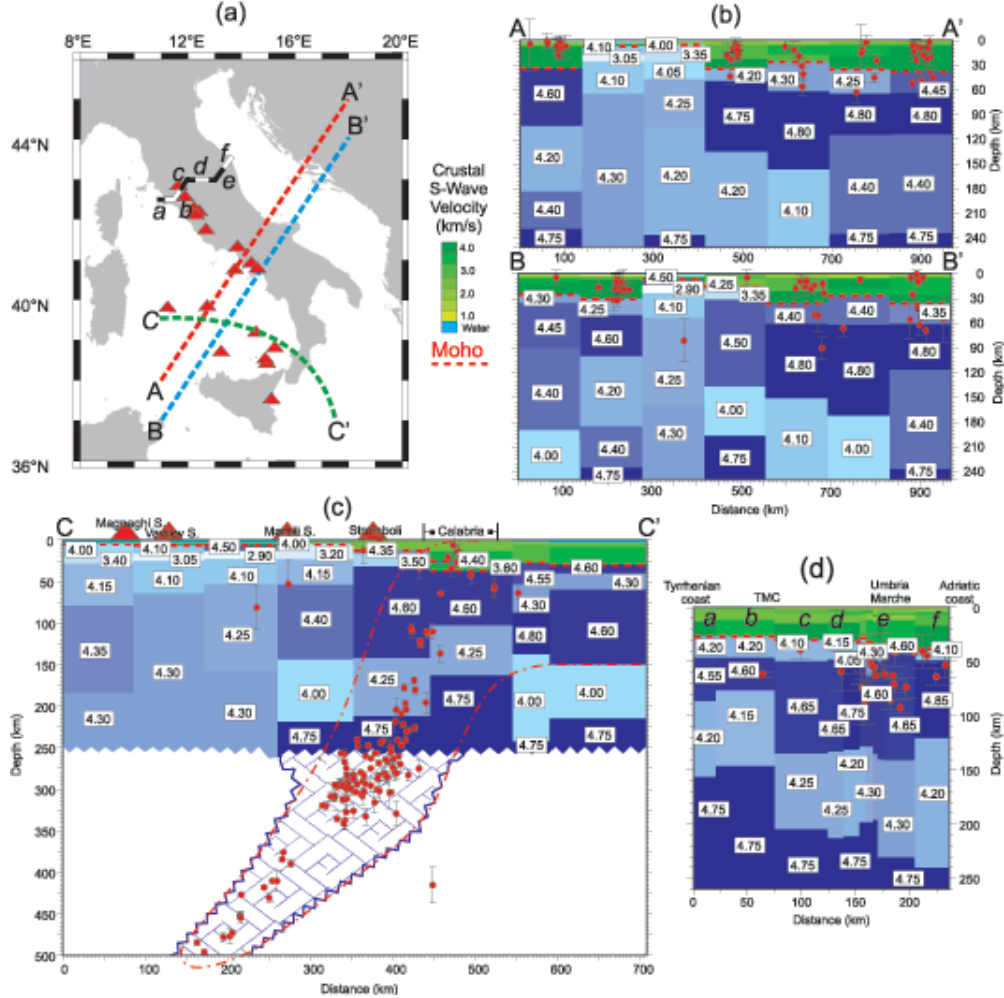
西

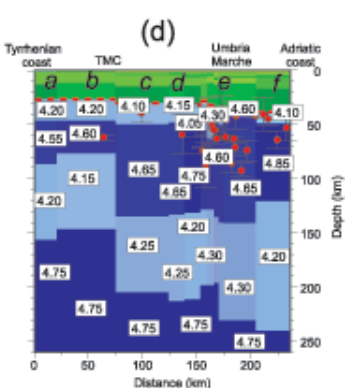

Figure 2 (a) Position of sections and of all recent volcanoes (triangles) (Amiata-Vulsini, Cimino-Vico-Sabatini, Albani, Roccamonfina, Phlegraean Fields-Vesuvio, Vulture, Ischia, Stromboli, Vulcano-Lipari, Etna, Ustica, Marsili, Magnaghi, Vavilov); (b) Tyrrhenian Sea-Southern ApenninesDinarides: the almost continuous high velocity body seen along BB' is not visible along AA'; (c) Tyrrhenian-Ionian Sea: outlined Ionian slab; shallow, intermediate-depth and deep earthquakes that fall into a band, about $100 \mathrm{~km}$ wide, along sections in (b) and (c), with the depth error bars being shown; (d) lithosphere-asthenosphere system from the Tyrrhenian (a) to the Adriatic coast $(f)$ and related intermediate-depth seismicity; the mantle wedge supports the lithospheric delamination beneath Central Italv 
hypocenters distribution of the intermediate-depth and deep seismicity. In correspondence to the shallow-mantle magma sources of the volcanic bodies Magnaghi-Vavilov and Marsili, low $\mathrm{V}_{\mathrm{s}}$ layers (very shallow asthenosphere) below the very soft thin lid are detected. A very low velocity layer (mantle wedge) below a thin uppermost lid in the Stromboli area and a lithospheric doubling beneath Calabria are seen. In the southernmost part of CC', the crustal thickness is about $30 \mathrm{~km}$ and the lithospheric upper mantle is characterized by a layering where a relatively low velocity body $\left(\mathrm{V}_{\mathrm{s}}\right.$ about $4.3 \mathrm{~km} / \mathrm{sec}$ ) lies between two fast ones. At depths greater than about $150 \mathrm{~km}$, a very well developed low velocity $\left(\mathrm{V}_{\mathrm{s}}\right.$ about $\left.4.0 \mathrm{~km} / \mathrm{sec}\right)$ asthenospheric layer is present. Crossing Calabria, the low velocity asthenospheric layer is absent and the relatively low velocity body $\left(\mathrm{V}_{\mathrm{s}}\right.$ about 4.25 $\mathrm{km} / \mathrm{sec}$ ) in the lithospheric mantle becomes deeper and thicker going towards west.

Figure $2 \mathrm{~d}$ shows the lithosphere-asthenosphere system along a stripe from the Tyrrhenian to the Adriatic coasts (Chimera et al., 2003), particularly detailed in UMD (see zone $e$ in Figure 2d). Beneath Central Italy high velocity bodies reach at least a depth of $130 \mathrm{~km}$ with a width of about $120 \mathrm{~km}$. The crust exhibits clear $\mathrm{V}_{\mathrm{s}}$ layering and lateral variation in thickness: less than $30 \mathrm{~km}$ below the Tuscan Metamorphic Complex (TMC) and about $35 \mathrm{~km}$ below UMD. The lid is thin (about $30 \mathrm{~km}$ ) below the TMC, while it is about $70 \mathrm{~km}$ thick below UMD. Along the profile, particularly in the western part where it gets shallower, a developed mantle wedge separates the crust from the high velocity lid.

\section{Maps of the lithosphere-asthenosphere}

The horizontal resolution of our maps is about $100 \mathrm{~km}$ and the vertical penetration reaches a depth of about $250 \mathrm{~km}$. All the features shown at depth larger than $250 \mathrm{~km}$ are schematically based on the intermediate-depth and deep seismicity, as given by ISC, schematised by dashed segments in Figures $3 b$ and $4 b, c$.

In Figures 3a,b, the Moho depth and the thickness of the lithosphere are shown, together with the recent volcanoes (red triangles).

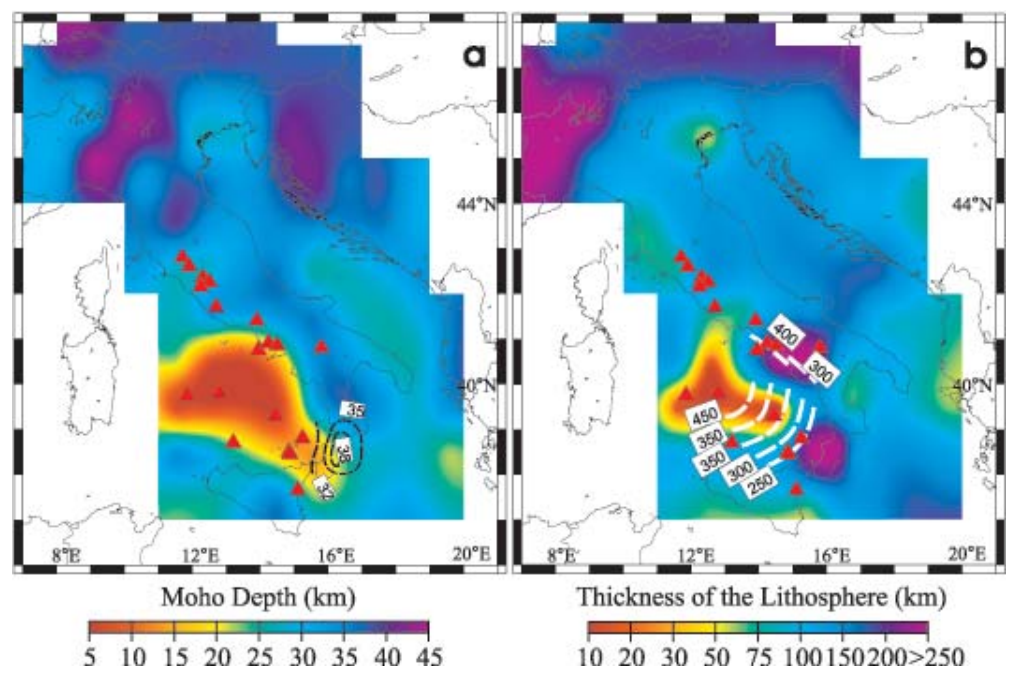

Figure 3 (a) Moho depth with contouring of the deeper Moho where lithospheric doubling is unambiguously detected; (b) thickness of the lithosphere. Here and in Figure 4, the dashed lines schematise the subduction of the Ionian-Adria lithosphere, traced accordingly with ISC hypocenters distribution, and red triangles mark the recent volcanoes.

In Figure 3a, the contouring of the deeper Moho indicates where lithospheric doubling is unambiguously detected by our data. In the northernmost area of the map in Figure 3b, the lithospheric thickness is about $200 \mathrm{~km}$, while in the Western Alps it is at least $250 \mathrm{~km}$. The lithospheric thickness varies in the range of about $100-150 \mathrm{~km}$ along the Northern Apennines, around the Padan plain and in the Dinarides area, except in its westernmost part, where the lithosphere is only about $80 \mathrm{~km}$ thick. The Northern Adriatic Sea has a lithosphere thinner than the Central-Southern Adriatic Sea. In the southernmost Adriatic Sea and in the Otranto channel area, the lithosphere is less than about $100 \mathrm{~km}$ thick. In the Calabrian and Campanian areas the lithospheric thickness exceeds $250 \mathrm{~km}$.

The two different dashing patterns in Figure $4 a$, where the $V_{s}$ just below the Moho is shown, indicate the presence of the mantle

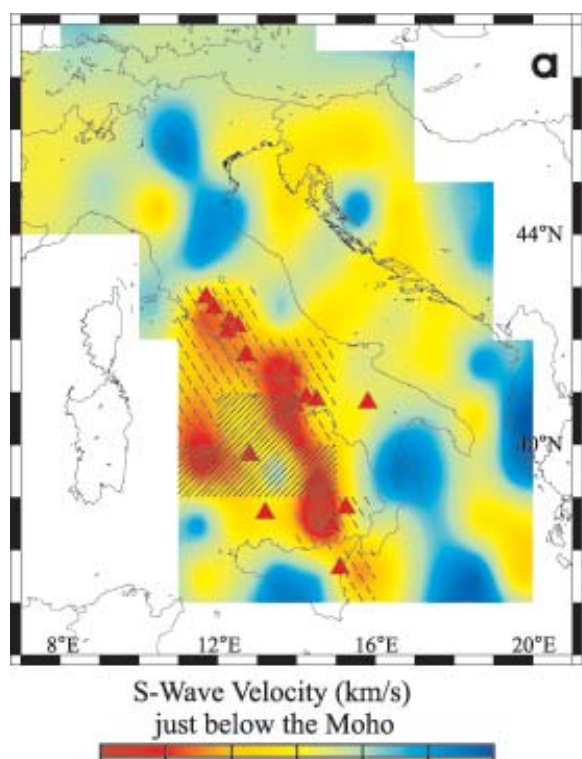

$\begin{array}{lllllll}3.85 & 4.00 & 4.15 & 4.30 & 4.50 & 4.60 & 4.80\end{array}$

Very shallow

Asthenosphere

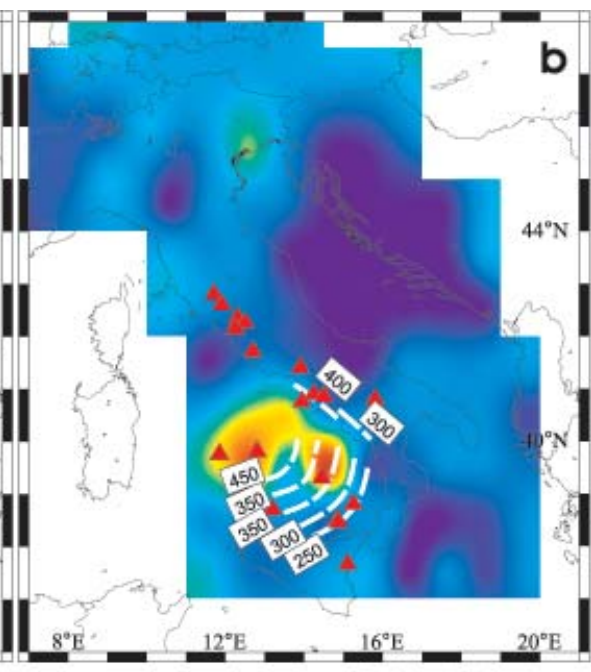

Maximum S-Wave Velocity $(\mathrm{km} / \mathrm{s})$ in the uppermost $200 \mathrm{~km}$

$\begin{array}{llllllll}4.0 & 4.1 & 4.2 & 4.3 & 4.4 & 4.5 & 4.6 & 4.8\end{array}$

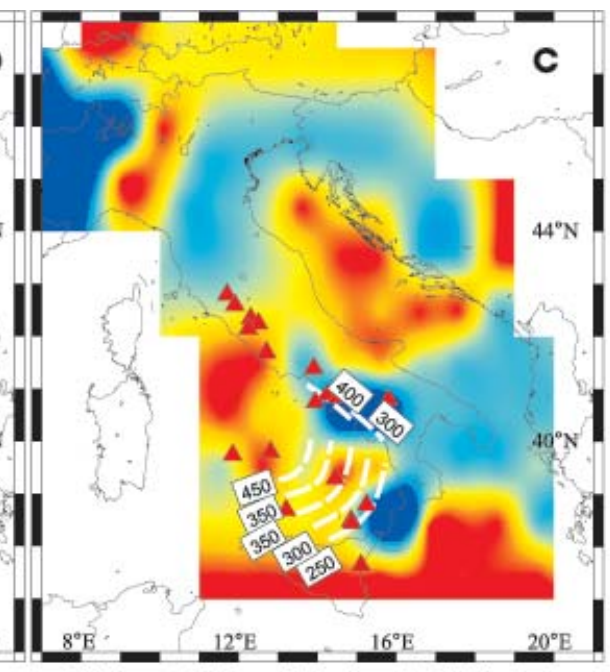

Minimum S-Wave Velocity $(\mathrm{km} / \mathrm{s})$ in the asthenosphere in the depth range from 80 to $220 \mathrm{~km}$

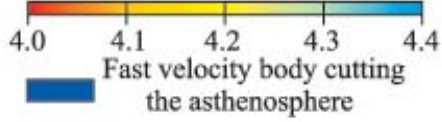

Figure 4 (a) $V_{s}$ just below the Moho (different dashed patterns outline where mantle wedge and a very shallow asthenosphere are detected); (b) maximum $V_{s}$ in the uppermost $200 \mathrm{~km}$; (c) minimum $V_{s}$ in the asthenosphere, in the depth range from about $80 \mathrm{~km}$ to about $220 \mathrm{~km}$ In $(c)$ the dark hlue areas indicate the fast velocitu hedies cuttine the asthenesho 
wedge and of a very shallow asthenosphere, respectively. Large lateral variations (Figure $4 \mathrm{~b}$ ) characterize the maximum $\mathrm{V}_{\mathrm{s}}$ in the uppermost $200 \mathrm{~km}$. Peak values are found in the western Alps, central Po valley, Dinarides, Central Adria, Southern-Central Apennines, Northern Tyrrhenian and Ionian Seas. In correspondence to all the volcanoes, except the Tyrrhenian Seamounts, the maximum lithospheric $\mathrm{V}_{\mathrm{s}}$ exceeds about $4.6 \mathrm{~km} / \mathrm{sec}$. Magnaghi-Vavilov and Marsili are separated by a region with relatively high $\mathrm{V}_{\mathrm{s}}$, but in correspondence to these volcanoes $V_{\mathrm{s}}$ is very low. The high-velocity bodies of the Ionian-Adria subducting slabs extend below the volcanoes of the Aeolian Arc and of the Campanian province. The minimum $\mathrm{V}_{\mathrm{s}}$ in the asthenosphere, in the depth range from about $80 \mathrm{~km}$ to about $220 \mathrm{~km}$, is shown in Figure 4c. The dark blue area in the northern part of the map corresponds to the fast velocity bodies present in the western Alps. East of this lithospheric body, the $\mathrm{V}_{\mathrm{s}}$ in the asthenosphere is as low as in the Northern Adriatic. The properties of the asthenosphere in the Northern Adriatic Sea $\left(\mathrm{V}_{\mathrm{s}}\right.$ between 4.0-4.1 $\mathrm{km} / \mathrm{sec}$ ), are different from those of the Southern Adriatic Sea and around the Otranto channel $\left(\mathrm{V}_{\mathrm{s}}\right.$ larger than about $\left.4.3 \mathrm{~km} / \mathrm{sec}\right)$. Low asthenospheric $\mathrm{V}_{\mathrm{s}}$ is seen in Sicily and in the Tyrrhenian and Ionian Sea. The dark blue areas around the Tyrrhenian Sea indicate the fast velocity Ionian-Adria slabs that cut the asthenosphere, and that can be traced at depth larger than $250 \mathrm{~km}$ from the distribution of subcrustal seismicity.

\section{Discussion}

In BB' (Figure 2b) the high-velocity body extending to depths not less than $250 \mathrm{~km}$ can be related to the westward subduction of the Adriatic lithosphere towards the Tyrrhenian Basin. This feature is in agreement with the results of De Gori et al. (2001). Along a section very close to AA' (Figure $2 \mathrm{~b}$ ) they find a weak velocity perturbation in the mantle beneath the mountain belt with a small high velocity anomaly dipping southwestward. This feature can be correlated with the layer with $\mathrm{V}_{\mathrm{s}}$ about $4.75 \mathrm{~km} / \mathrm{sec}$, whose top is at about $220 \mathrm{~km}$, in AA'. The rising of the bottom of the asthenosphere could be caused by remnants of high velocity bodies probably detached (Wortel and Spakman, 2002 and references therein) from the lithospheric roots, through thermo-mechanical processes. The remarkable difference between the two sections of Figure 2b, confirmed by completely independent data, indicates that the subducted lithosphere has a very complex morphology.

In CC' (Figure 2c), the body with $\mathrm{V}_{\mathrm{s}}$ about $4.4 \mathrm{~km} / \mathrm{sec}$ near the center, above the slab, is probably due to thermal effects induced by the mechanical interaction between the Ionian lithosphere and the hot Tyrrhenian upper mantle. In the center of the section, the layer with $\mathrm{V}_{\mathrm{s}}$ around $4.0 \mathrm{~km} / \mathrm{sec}$, extending from about $140 \mathrm{~km}$ to $220 \mathrm{~km}$ depth, can be explained by dehydration processes and melting along the down-going slab (e.g. Goes et al., 2000 and references therein). The layering along the easternmost half of CC', in the Ionian area, seems to be consistent with the subduction of serpentinized and attenuated continental lithosphere, formed in response to the Jurassic extensional phase. During the tensional phase, the relatively low velocity $\left(\mathrm{V}_{\mathrm{s}}\right.$ in the range $4.25-4.30 \mathrm{~km} / \mathrm{sec}$ ) layer could be formed as a result of the serpentinization of peridotites. Such process produces $\mathrm{V}_{\mathrm{s}}$ retardations of a few percent (Christensen, 1966). The presence of a low velocity layer of chemical and not of thermal origin is consistent with the low heat flow in the Ionian Sea (Della Vedova et al., 1991). This layer, when subducted, gets thicker, consistently with the dehydration of serpentine, which is responsible for the weakening of the neighboring material. The seismicity is distributed along the slab and it seems to decrease, but it is not absent, in correspondence with the serpentinized layer. In the studied part of the Ionian Sea, the lithosphere is attenuated continental, thermally relaxed after the Jurassic extensional phase, while in the Southern Tyrrhenian Sea it is very young oceanic.

Beneath Central Italy (see Figure 2d) there is clear evidence of
Young magmatism at the surface and high heat flow in the TMC region suggest that, in agreement with petrological and geochemical data (Peccerillo et al., 2001), this layer may represent a partially molten mantle. In Tuscany, the mantle wedge is underlined by a thin lithosphere and an up-risen asthenosphere roof, in agreement with the heat flow data (Della Vedova et al., 1991). Along the same vertical section, the rising of the bottom of the asthenosphere may have the same origin discussed for section AA' (Figure 2b). The subcrustal earthquakes (ISC) cluster in the shallower part of the thick Adriatic lid and in the eastern part of the lithospheric root, consistently with a slab-like geometry, while the part of the lithospheric root and thin lid to the west seems to be almost free of seismic activity. The absence of deep seismicity and the non-in-depth continuity of the fast velocity body below Central Apennines (Figure 2d) and Southern Apennines (Figure 2b) clearly highlight a major difference when compared to the structure and related deep seismicity of the Calabrian arc, where there is sound evidence of a continuous slab.

The complex crustal structure, where shearing and thrusting involve the whole crust and the upper mantle, causing the occurrence of more than one Moho, as described by Nicolich and Dal Piaz (1990), is confirmed by our data and the map in Figure 3a reproduces several other features identified by the same authors. Near the Otranto channel the Moho is in the range of $25-30 \mathrm{~km}$, i.e. shallower with respect to the results of Nicolich and Dal Piaz (1990), but well in agreement with the Moho depth proposed by Herak and Herak (1995).

In Figure 3b, the Western Alps lithosphere at least $250 \mathrm{~km}$ thick is consistent with the presence of the lithospheric root (Panza and Mueller, 1979). The Northern Adriatic Sea has a lithosphere thinner than the Central-Southern Adriatic Sea, where a band with moderate seismicity can be identified. The lithosphere is very thin, less than $20 \mathrm{~km}$, in correspondence to Magnaghi, Vavilov and Marsili. The lithospheric thickness exceeding $250 \mathrm{~km}$ in the Campanian and Calabrian areas is associated with the subduction of the Ionian-Adria lithosphere, schematically represented, for depths larger than 250 $\mathrm{km}$, by the isolines in Figure $3 \mathrm{~b}$.

The mantle wedge area shown in Figure 4a is in agreement with what proposed by Meletti et al. (2000) in their structural and kinematic model of Italy. In some cases, the lowest velocity material is not just below the Moho but below a thin mantle lid, possibly formed by thermal underplating. All the volcanic areas (see the caption of Figure 2), except those with the inactive volcanoes of Vulture and Ustica, are characterized by the presence of a low velocity layer just below the Moho or below a very thin lid.

The dark blue area in the northern part of Figure $4 c$, due to the plate collision process between Eurasian and African plates, contains the so-far proposed locations of the rotation pole of Adria versus Europe (Meletti et al., 2000 and references therein).

\section{Acknowledgements}

Research funded by Italian MIUR Cofin-2001 (2001045878_007), Cofin-2002 (2002047575_002), CNR (CNRC007AF8), and INGV2001. We thank F. Wezel for critically reading the manuscript.

\section{References}

Alessandrini, B., Beranzoli, L., and Mele, F.M., 1995, 3D crustal P-wave velocity tomography of the Italian region using local and regional seismicity data, Ann. Geof., v. 38, no 2, pp. 189-211.

Alessandrini, B., Beranzoli, L., Drakatos, G., Falcone, C., Karantonis, G., Mele, F.M., and Stavrakakis, G.N., 1997, Tomographic image of the crust and uppermost mantle in the Ionian and Aegean regions, Annali di Geofis., v. 40, no 1, pp. 151-160.

Aljinovic, B., and Blaskovic, I., 1987, Some characteristics of the carbonate complex in the offshore Adriatic area, Mem. Soc. Geol. It., v. 40, pp. 327-334.

Babuska, V., and Plomerova, J., 1990, Tomographic studies of the upper 
Bally, A.W., Burbi, L., Cooper, C., and Ghelardoni, R., 1986, Balanced sections and seismic reflection profiles across the Central Apennines, Mem. Soc. Geol. It., v. 35, pp. 257-310.

Bijwaard, H., Spakman, W., and Engdahl, E.R., 1998, Closing the gap between regional and global travel time tomography, J. Geophys. Res., v. 103, pp. 30.055-30.078

Blundell, D., Freeman, R., and Mueller, St., 1992, A continent revealed, The European geotraverse, University press, Cambridge.

Bottinga, Y., and Steinmetz, L., 1979, A geophysical, geochemical, petrological model of the sub-marine lithosphere, Tectonophysics, v. 55, pp. 311-347.

Catalano, R., Di Stefano, P., Sulli, A., and Vitale, F.P., 1996, Paleogeography and structure of the central Mediterranean: Sicily and its offshore area, Tectonophysics, v. 260, pp. 291-323.

Catalano, R., Doglioni, C., and Merlini, S., 2001, On the Mesozoic Ionian Basin, Geophys. J. Int., v. 144, pp. 49-64.

Cernobori, L., Hirn, A., McBride, J.H., Nicolich, R., Petronio, L., Romanelli, M., and STREAMERS/PROFILES Working Groups, 1996, Crustal image of the Ionian basin and its Calabrian margin, Tectonophysics, v. 264, pp. 175-189.

Chimera, G., Aoudia, A., Saraò, A., and Panza, G.F., 2003, Active tectonics in central Italy: constraints from surface wave tomography and source moment tensor inversion, Phys. Earth Planet. Int. (in press).

Christensen, N.I., 1966, Elasticity of Ultrabasic Rocks, J. Geophys. Res., v. 71, no 24, pp. 5921-5931.

Cimini G.B., and De Gori, P., 1997, Upper mantle velocity structure beneath Italy from direct and secondary P-wave teleseismic tomography, Annali di Geofis., v. XL, no 1, pp. 175-194

Cristofolini, R., Ghisetti, F., Scarpa, R., And Vezzani, L., 1985, Character of the stress field in the Calabrian Arc and Southern Apennines (Italy) as deducted by geological, seismological and volcanological information, Tectonophysics, v. 117, pp. 39-58.

De Gori, P, Cimini, G.B., Chiarabba, C., De Natale, G., Troise, C., and Deschamps, A., 2001, Teleseismic tomography of the Campanian volcanic area and surrounding Apenninic belt, J. Volc. and Geoth. Res., v. 109, pp. 55-75.

Della Vedova, B., Marson, I., Panza, G.F., and Suhadolc, P., 1991, Upper mantle properties of the Tuscan-Tyrrhenian area: a framework for its recent tectonic evolution, Tectonophysics, v. 195, pp. 311-318.

De Voggd, B., Truffert, C., Chamot-Rooke, N., Huchon, P., Lallermant, S. and Le Pichon, X., 1992, Two-ship deep seismic soundings in the basins of the Eastern Mediterranean Sea (Pasiphae cruise), Geophys. J. Int., v. 109, pp. 536-552.

Ditmar, P.G., and Yanovskaya, T.B., 1987, A generalization of the BackusGilbert method for estimation of lateral variations of surface wave velocity, Izv. AN SSSR, Fiz. Zemli (Physics of the Solid Earth), v. 23, no 6, pp. 470-477.

Doglioni, C., Innocenti, F., and Mariotti, G., 2001, Why Mt. Etna? Terra Nova, v. 13, pp. 25-31.

Du, Z.J., Michelini, A., and Panza, G.F., 1998, EurID: a regionalised 3-D seismological model of Europe, Phys. Earth Planet. Inter., v. 105, pp. 31-62.

Ferrucci, F., Gaudiosi, G., Hirn, A., and Nicolich, R., 1991, Ionian Basin and Calabrian Arc: some new elements from DSS data, Tectonophysics, v. 195, pp. 411-419.

Finetti, I.R., Boccaletti, M., Bonini, M., Del Ben, A., Geletti, R., Pipan, M., and Sani, F., 2001, Crustal section based on CROP seismic data across the North Tyrrhenian-Northern Apennines-Adriatic Sea, Tectonophysics, v. 343, pp. 135-163.

Gentile, G., Bressan, G., Burlini, L., and De Franco, R., 2000, Three-dimensional $V_{p}$ and $V_{p} / V_{s}$ models of the upper crust in the Friuli area (northeastern Italy), Geophys. J. Int., v. 141, pp. 457-478.

Gobarenko, V.S., Nikolova, S.B., and Sokolova, S.J., 1990, Velocity structure of the western Mediterranean from inversion of P-wave traveltimes, Geophys. J. Int., v. 101, pp. 557-564.

Goes, S., Govers, R., and Vacher, P., 2000, Shallow mantle temperatures under Europe from P and S wave tomography, J. Geophys. Res., v. 105, pp. 11.153-11.169.

Herak, D., and Herak, M., 1995, Body-wave velocities in the circum-Adriatic region, Tectonophysics, v. 241, pp. 121-141.

Improta, L., Iannaccone, G., Capuano, P., Zollo, A., and Scandone, P., 2000, Inferences on the upper crustal structure of Southern Apennines (Italy) from seismic refraction investigations and surface data, Tectonophysics, v. 317, pp. 273-297.

ISC.International Seismological Centre On-line Bulletin, http://www.isc.ac.uk/Bull, Internat. Seis. Cent., Thatcham, United Kingdom.

Karagianni, E.E., Panagiotopoulos, D.G., Panza, G.F., Suhadolc, P., Papaza-
Priestley, K., and Vuan, A., 2002, Rayleigh Wave Group Velocity Tomography in the Aegean area, Tectonophysics, v. 358, pp. 187-209.

Kissling E., and Spakman, W., 1996, Interpretation of tomographic images of uppermost mantle structure: examples from the western and central Alps, J. Geodyn., v. 21, pp. 97-111.

Knopoff, L., 1972, Observations and inversion of surface-wave dispersion, in: The Upper Mantle, Tectonophysics, Ritsema A.R. ed., v. 13, pp. 497-519.

Knopoff, L., and Panza, G.F., 1977, Resolution of Upper Mantle Structure using higher modes of Rayleigh waves, Annales Geophysicae , v. 30, pp. 491-505.

Levshin, A.L., Pisarenko, V.F., and Pogrebinsky, G.A., 1972, On a frequency time analysis of oscillations, Annales Geophysicae, v. 28, pp. 211-218.

Levshin, A.L., Ratnikova, L., and Berger, J., 1992, Peculiarities of surface wave propagation across Central Eurasia, Bull. Seismol. Soc. Am., v. 82, pp. 2464-2493.

Lucente, F.P., Chiarabba, C., Cimini G.B., and Giardini, D., 1999, Tomographic constraints on the geodynamic evolution of the Italian region, J. Geophys. Res., v. 104, pp. 20.307-20.327.

Marquering, H., and Snieder, R., 1996, Shear-wave velocity structure beneath Europe, the north-eastern Atlantic and western Asia from waveform inversion including surface-wave mode coupling, Geophys. J. Int. v. 127 , pp. 283-304.

Martinez, M.D., Lana, X., Badal, J., Canas, J.A., and Pujades, L., 1997, Preliminary objective regionalization of the Mediterranean basin derived from surface-wave tomography, Annali di Geofis., v. XL, no 1, pp. 43-59.

Martinez, M.D., Lana, X., Canas, J.A., Badal, J., and Pujades, L., 2000, Shear-wave velocity tomography of the lithosphere-asthenosphere system beneath the Mediterranean area, Phys. Earth and Plan. Int., v. 122, pp. $33-54$

Martinez, M.D., Canas, J.A., Lana, X., and Badal, J., 2001, Objective regionalization of Rayleigh wave dispersion data by clustering algorithms: an application to the Mediterranean basin, Tectonophysics, v. 330, pp. 245-266.

Meletti, C., Patacca, E., and Scandone, P., 2000, Construction of a Seismotectonic Model: The Case of Italy, Pure Appl. Geophys., v. 157, pp. 1135 .

Morelli, C., 1998, Lithospheric structure and geodynamics of the Italian peninsula derived from geophysical data: a review, Mem. Soc. Geol. It., v. 52, pp. 113-122.

Mostaanpour, M.M., 1984, Einheitliche Auswertung krustenseismicher daten in Westeuropa. Darstellung von Krustenparametern und Laufzeitanomalien. Verlag von Dirtrich Reimer in Berlin.

Nicolich, R., and Dal Piaz, R., 1990, Moho isobaths. in Structural model of Italy and Gravity Map, Sheet 2, Consiglio Nazionale delle Ricerche.

Panza, G.F., and Mueller, S., 1979, The plate boundary between Eurasia and Africa in the Alpine area, Memorie di Scienze Geologiche, Università di Padova, v. 33, pp. 43-50.

Panza, G.F., Mueller, S., and Calcagnile, G., 1980, The gross features of the lithosphere-asthenosphere system in Europe from seismic surface waves and body waves, Pure Appl. Geoph., v. 118, pp. 1209-1213.

Panza, G.F., 1981, The resolving power of seismic surface waves with respect to crust and upper mantle structural models, in The solution of the inverse problem in geophysical interpretation. Cassinis R. ed., Plenum Publ. Corp., pp. 39-77.

Panza, G.F., and Pontevivo, A., 2002, The Lithosphere-Asthenosphere System in the Calabrian Arc and surrounding seas, Preprint ICTP, IC/2002/141.

Panza, G.F., Pontevivo, A., Saraò, A., Aoudia, A., and Peccerillo, A., 2003a, Structure of the Lithosphere-Asthenosphere and Volcanism in the Tyrrhenian Sea and surroundings, Preprint ICTP, IC/2003/8.

Panza, G.F., Raykova, R., Chimera, G., and Aoudia, A., 2003b, Multiscale surface wave tomography in the Alps (abs), Transalp Conference, Trieste, February 2003.

Papazachos, C.B., Hatzidimitriou, P.M., Panagiotopoulos, D.G., and Tsokas, G.N., 1995, Tomography of the crust and upper mantle in southeast Europe, J. Geophys. Res., v. 100, pp. 12405-12422.

Papazachos, C.B., and Kiratzi, A.A., 1996, A detailed study of the active crustal deformation in the Aegean and surrounding area, Tectonophysics, v. 253 , pp. $129-153$.

Parolai, S., Spallarossa, D., and Eva C., 1997, Bootstrap inversion for Pn wave velocity in North-Western Italy, Annali di Geofis., v. XL, no 1, pp. 133-150.

Pasyanos, M.E., Walter, W.R., and Hazler, S.E., 2001, A surface wave dispersion study of the Middle East and North Africa for Monitoring the Compressive Nuclear-Test-Ban Treaty, Pure Appl. Geophys., v. 158, pp. 
Peccerillo, A., 2001, Geochemical similarities between the Vesuvius, Phlegraean Fields and Stromboli Volcanoes: petrogenetic, geodynamic and volcanological implications, Mineralogy and Petrology, v. 73, pp. 93-105.

Pepe, F., Bertotti, G., Cella, F., and Marsella, E., 2000, Rifted margin formation in the south Tyrrhenian Sea: a high-resolution seismic profile across the north Sicily passive continental margin, Tectonics, v. 19, no 2, pp. 241-257.

Pialli, G., Alvarez, W., and Minelli, G., 1995, Geodinamica dell'Appennino settentrionale e sue ripercussioni nella evoluzione tettonica miocenica, Studi geol. Camerti, Volume speciale 1995, no 1, pp. 523-536.

Pialli, G., Barchi, M., and Minelli, G., 1998, Results of the CROP03 deep seismic reflection profile, Mem. Soc. Geol. It., v. 52.

Piromallo, C., and Morelli, A., 1997, Imaging the Mediterranean upper mantle by P-wave travel time tomography, Ann. Geof., v. 40, no 4, pp. 963-979.

Pontevivo, A., and Panza, G.F., 2002, Group Velocity Tomography and Regionalization in Italy and bordering areas, Phys. Earth Planet. Inter., v. 134, pp. 1-15.

Ritzwoller, M.H., and Levshin, A.L., 1998, Eurasian surface wave tomography: Group velocities, J. Geophys. Res., v. 103, pp. 4839-4878.

Russell, B., 1946, History of western philosophy, George Allen and Unwind, Ltd.

Scarascia, S., and Cassinis, R., 1997, Crustal structures in the central-eastern Alpine sector: a revision of the available DSS data, Tectonophysics, v. 271, pp. 157-188.

Spakman, W., 1990, Tomographic images of the upper mantle below central Europe and the Mediterranean, Terra Nova, v. 2, pp. 542-553.

Valyus, V.P., Keilis-Borok, V.I., and Levshin, A., 1969, Determination of the upper-mantle velocity cross-section for Europe, Proc. Acad. Sci. USSR, v. 185 , no 3 .

Valyus, V.P., 1972, Determining seismic profiles from a set of observations. in Computational Seismology, Keilis-Borok ed., Consult. Bureau, NewYork, pp. 114-118.

Yanovskaya, T.B., and Ditmar, P.G., 1990, Smoothness criteria in surfacewave tomography, Geophys. J. Int., v. 102, pp. 63-72.

Yanovskaya, T.B., Kizima, E.S., and Antonova, L.M., 1998, Structure of the crust in the Black Sea and adjoining regions from surface wave data, J. Seismol., v. 2, pp. 303-316.

Yanovskaya, T.B., Antonova, L.M., and Kozhevnikov, V.M., 2000, Lateral variations of the upper mantle structure in Eurasia from group velocities of surface waves, Phys. Earth Planet. Inter., v. 122, pp 19-32.

Wortel, M.J.R., and Spakman, W., 2002, Subduction and Slab Detachment in the Mediterranean-Carpathian Region, Science, v. 290, pp. 1910-1916.

Giuliano F. Panza, Professor of seismology in the Department of Earth Sciences - University of Trieste, and head of SAND Group ICTP-Trieste. Laurea in physics from the University of Bologna in 1967; PostDoc at UCLA. He is fellow of Academia Nazionale dei Lincei, of Academia Europea, and Third World Academy of Sciences. He is winner of the EGS Beno Gutermberg medal in 2000, and received Laurea Honoris Causa in Physics in 2002 from the University of Bucharest. He is leader of several projects funded by EC related to seismic hazard assessment.
Antonella Pontevivo, PhD from the este in 1999. At present PostDoc in surroundings.

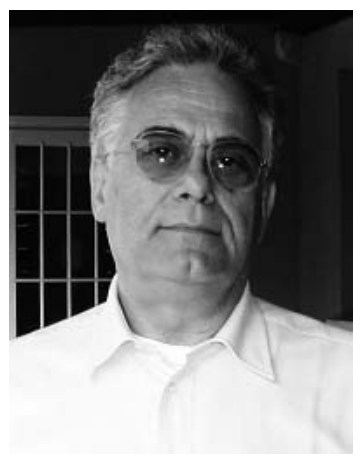
Department of Earth Sciences -University of Trieste in 2003. Laurea in physics from the University of Trithe Geological Institute - University of Copenhagen. Her PhD thesis is on surface-wave tomography, nonlinear inversion and geophysical implications in the Italian area and

Giordano Chimera is PhD-student in the Department of Earth Sciences University of Trieste. He received his Laurea in physics from the University of Trieste in 1998. His interests are: tomography and non-linear inversion in the Apenninic and Alpine areas.

Reneta Raykova, Laurea in physics from the University of Sofia in 1994. As PhD student in the Department of Seismology at the Geophysical Institute of Sofia, she received in 2003 from the Department of Earth Sciences - University of Trieste, a one year EU - Marie Curie fellowship. Her interests are surface wave tomography and structure of the crust and upper mantle.
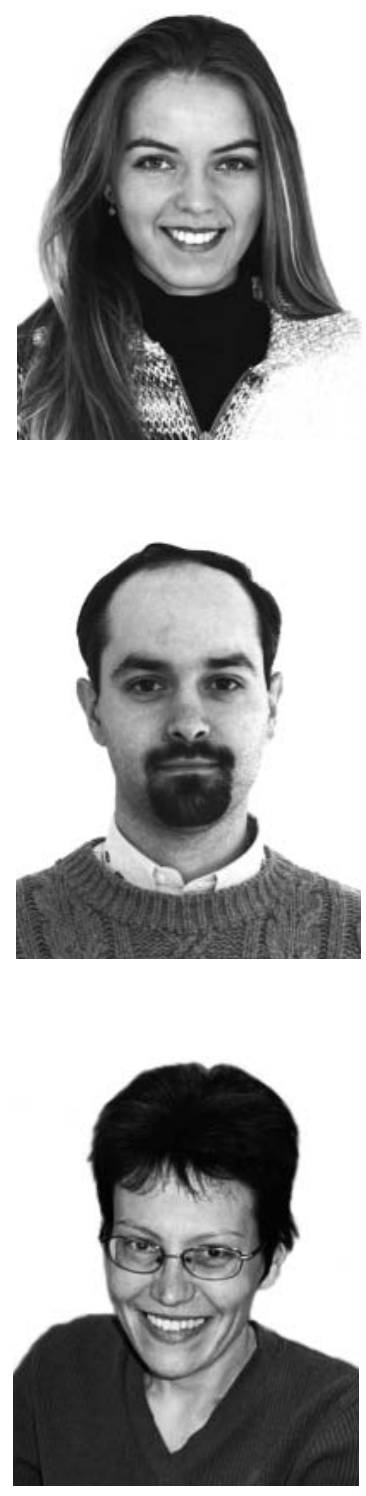

Abdelkrim Aoudia, research scientist at the International Centre for Theoretical Physics at Trieste. He received his $P h D$ in geophysics from the University of Trieste in 1998. His research interests revolve around using geophysical, geodetic and tectonic data to understand the mechanical behavior of earthquake faults and to constrain better conceptual and quantitative models for lithospheric deformation.

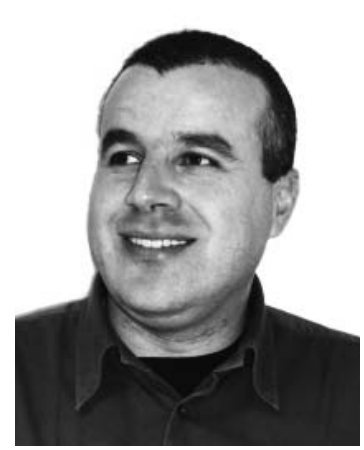

